\title{
Analysis of Independence Completing The Assignment in Entrepreneurship Learning Class IV Students at SD Negeri 2 Waluyo
}

\section{Fenti Retnoningrum, Rokhmaniyah}

Universitas Sebelas Maret

fentiretnoningrum26@gmail.com

\section{Article History}

accepted 24/09/2019

approved 01/10/2019

published 01/12/2019

\begin{abstract}
In entrepreneurship learning, students are required to complete assignments independently with the intention of creating an independent, responsible, and good entrepreneurial generation. This study aims to describe the independence of students in completing assignments in the fourth grade entrepreneurship learning process at SDN 2 Waluyo. This research approach uses a qualitative approach and descriptive research type. The subjects of this study were students in class IV at SDN 2 Waluyo, totaling 28 students. Data collection was carried out using observation techniques, questionnaires, and classroom teacher interviews. The results of this study indicate that independence in the good category is self-confidence, being able to work alone, respecting time, and being responsible. While independence is in the sufficient category is to have the desire to compete to move forward and be able to make decisions.
\end{abstract}

Keywords: Independence, Entrepreneurship Learning

\section{Abstrak}

Dalam pembelajaran kewirausahaan, siswa dituntut untuk menyelesaikan tugas secara mandiri dengan maksud menciptakan generasi muda yang mandiri, bertanggungjawab, dan memiliki jiwa kewirausahaan yang baik. Penelitian ini bertujuan untuk mendeskripsikan kemandirian siswa dalam menyelesaikan tugas pada proses pembelajaran kewirausahaan kelas IV di SDN 2 Waluyo. Pendekatan penelitian ini menggunakan pendekatan kualitatif dan tipe penelitian deskriptif. Subjek penelitian ini adalah siswa kelas IV di SDN 2 Waluyo yang berjumlah 28 siswa. Pengumpulan data dilakukan dengan teknik observasi, angket, dan wawancara guru kelas. Hasil dari penelitian ini menunjukkan bahwa kemandirian yang berada pada kategori baik adalah percaya diri, mampu bekerja sendiri, menghargai waktu, dan bertanggung jawab. Sedangkan kemandirian yang berada pada kategori cukup adalah memiliki hasrat bersaing untuk maju dan mampu mengambil keputusan.

Kata kunci: Kemandirian, Pembelajaran Kewirausahaan

Social, Humanities, and Education Studies (SHEs): Conference Series https://jurnal.uns.ac.id/shes 


\section{PENDAHULUAN}

Dalam proses pembelajaran setiap peserta didik selalu diarahkan agar menjadi siswa yang mandiri. Dalam perkembangannya kemandirian muncul sebagai hasil proses belajar dan pengalaman. Kemandirian berasal dari kata mandiri yang berarti berdiri sendiri, yaitu suatu keadaan yang memungkinkan seseorang mengatur dan mengarahkan diri sendiri sesuai tingkat perkembangannya (Tursinawati, 2017). Sedangkan Ali dan Asrori (2012:110), menyatakan "Kemandirian merupakan suatu kekuatan internal yang diperoleh melalui proses realisasi kemandirian dan proses menuju kesempurnaan". Kemandirian belajar merupakan salah satu faktor yang menentukan keberhasilan siswa dalam belajar. Orang tua mempunyai peranan yang sangat penting dalam membentuk kemandirian pada diri anak-anaknya. Hal ini disebabkan karena orangtualah yang menjadi pendidik pertama dalam keluarga. Dengan kata lain, orang tua menjadi penanggung jawab pertama dan utama terhadap pendidikan anak-anaknya. Dalam pembelajaran di sekolah, guru memiliki peran penting untuk menumbuhkan dan mengembangkan kemandirian siswa.

Dalam pembelajaran kewirausahan di sekolah dasar, kemandirian siswa dapat ditentukan ketika siswa mampu atau tidak dalam menyelesaikan suatu permasalahan yang dihadapi. Kemandirian siswa dalam pembelajaran kewirausahaan biasanya ditandai dengan kemampuan bekerja sendiri, kreatif dan inisiatif, mengatur tingkah laku, bertanggung jawab, mampu menahan diri, membuat keputusan sendiri, serta mampu mengatasi masalah tanpa ada pengaruh dari orang lain. Gea (2012:195) mengatakan bahwa "individu dikatakan mandiri apabila memiliki lima ciri sebagai berikut: 1) percaya diri, 2) mampu bekerja sendiri, 3) menghargai waktu, 4) tanggung jawab, 5) memiliki hasrat bersaing untuk maju, dan 6) mampu mengambil keputusan". Keenam ciri-ciri individu mandiri tersebut, dapat dijelaskan sebagai berikut: 1) percaya diri, adalah meyakini pada kemampuan dan penilaian diri sendiri dalam melakukan tugas dan memilih pendekatan yang efektif, 2) mampu bekerja sendiri, adalah usaha yang dilakukan secara mandiri untuk menghasilkan sesuatu yang membanggakan atas kesungguhan dan keahlian yang dimilikinya, 3) menghargai waktu, adalah kemampuan mengatur jadwal yang diprioritaskan dalam kegiatan yang bermanfaat secara efesien, 4) tanggung jawab adalah segala sesuatu yang harus dijalankan atau dilakukan oleh seseorang dalam melaksanakan sesuatu yang sudah menjadi pilihannya, 5) memiliki hasrat bersaing untuk maju adalah suatu kondisi dimana individu memiliki rasa ingin tahu dan tingkat kekreativitasan yang tinggi dalam mencapai tujuan, dan 6) mampu mengambil keputusan adalah suatu hasil dari proses mental atau kognitif yang membawa pada pemilihan suatu jalur tindakan di antara beberapa alternatif yang tersedia.

Kenyataan di lapangan berdasarkan informasi awal sebelum observasi dari wawancara guru kelas di SD Negeri 2 Waluyo, siswa belum sepenuhnya memiliki nilai kemandirian yang baik, khususnya siswa kelas IV. Hal ini dapat dilihat dari permasalahan yang terjadi diantaranya adalah siswa meminta guru untuk mengarahkan secara terus menerus dalam kegiatan belajar, siswa membutuhkan dukungan dari orang lain yang berlebihan dalam menyelesaikan masalah sendiri, siswa sering menyontek pekerjaan teman saat ada tugas maupun saat ulangan berlangsung, siswa tidak memiliki tanggung jawab dalam melaksanakan tugas, dan siswa selalu ingin cepat-cepat mengakhiri kegiatan belajarnya. Hal-hal tersebut menggambarkan bahwa nilai kemandirian dalam diri siswa belum berkembang secara optimal. Apabila keadaan yang seperti ini tidak segera ditangani, dikhawatirkan akan berpengaruh terhadap prestasi belajar siswa di sekolah. Sehingga perlu adanya upaya yang dilakukan untuk mendorong kemandirian siswa dalam belajar.

Berdasarkan latar belakang di atas, peneliti tertarik untuk melakukan penelitian dengan judul "Analisis Kemandirian Menyelesaikan Tugas dalam Pembelajaran Kewirausahaan Siswa Kelas IV di SD Negeri 2 Waluyo". Penelitian ini bertujuan untuk 
mendeskripsikan kemandirian siswa dalam menyelesaikan tugas pada proses pembelajaran kewirausahaan kelas IV di SDN 2 Waluyo.

\section{METODE}

Pendekatan penelitian ini adalah kualitatif deskriptif. Subjek penelitian ini adalah 1 orang guru dan siswa kelas IV SD Negeri 2 Waluyo yang berjumlah 28 orang yang terdiri dari 12 siswa perempuan dan 16 siswa laki-laki. Penelitian ini dilaksanakan di SD Negeri 2 Waluyo pada semester ganjil tahun ajaran 2019/2020. Pengumpulan data dengan teknik observasi, angket, dan wawancara guru kelas. Teknik analisis data menggunakan Teknik Triangulasi dimana dalam teknik ini pengumpulan data bersifat penggabungan dari berbagai teknik dan menggunakan tiga langkah pengolahan data, yakni reduksi, menyajikan data, dan mengambil kesimpulan (Sugiyono, 2013: 330). Data dianalisis dengan rumus deskriptif persentase menurut Ali (2013: 201), sebagai berikut:

$$
\text { Skor }=\frac{\text { Jumlah Skor }}{\text { Skor Maksimal }} \times 100 \%
$$

Rumus ini bisa digunakan untuk mengkonversikan jawaban dari data yang telah dihitung. Adapun skalanya sebagai berikut:

\begin{tabular}{cc}
\hline \multicolumn{2}{c}{ SKALA PERSENTASE DATA } \\
\hline PERSENTASE & KETERANGAN \\
$90 \%-100 \%$ & Sangat Baik \\
$80 \%-89 \%$ & Baik \\
$70 \%-79 \%$ & Cukup Baik \\
$50 \%-69 \%$ & Kurang Baik \\
$<49 \%$ & Kurang Sekali \\
\hline \multicolumn{2}{c}{ (Riduwan, 2012: 89 ) }
\end{tabular}

Selain itu, data kualitatif yang lain dalam penelitian ini diperoleh dari wawancara guru yang digunakan untuk mempertegas jawaban instrumen observasi kemudian dideskripsikan dalam pembahasan.

\section{HASIL DAN PEMBAHASAN}

Berdasarkan hasil penelitian yang telah dilaksanakan pada SD $\mathrm{N} 2$ Waluyo diperoleh bahwa kemandirian menyelesaikan tugas dalam pembelajaran kewirausahaan dinilai dari aspek percaya diri, mampu bekerja sendiri, menghargai waktu, bertanggung jawab, memiliki hasrat bersaing untuk maju, dan mampu mengambil keputusan. Data dalam penelitian dideskripsikan dalam diagram batang yang didapatkan dari angket dan instrumen observasi yang diperkuat dengan wawancara. 
Hasil Penelitian menggunakan angket

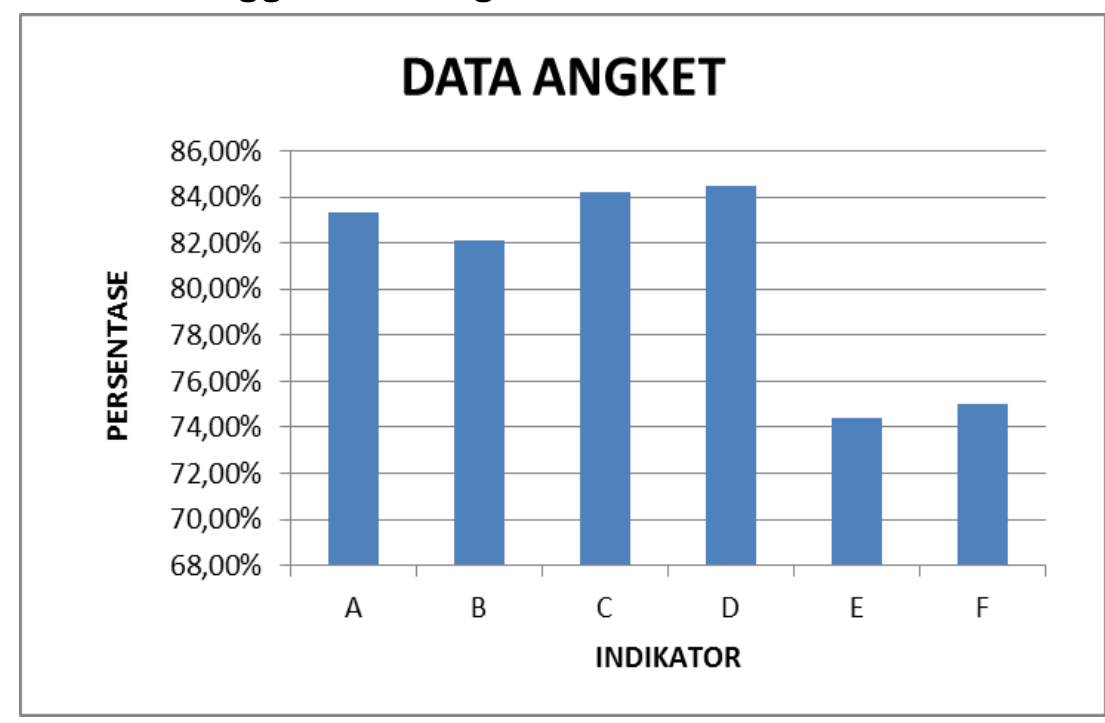

Gambar 1. Diagram profil kemandirian dalam menyelesaikan tugas dalam pembelajaran kewirausahaan kelas IV menggunakan angket

Hasil Penelitian menggunakan Instrumen Observasi

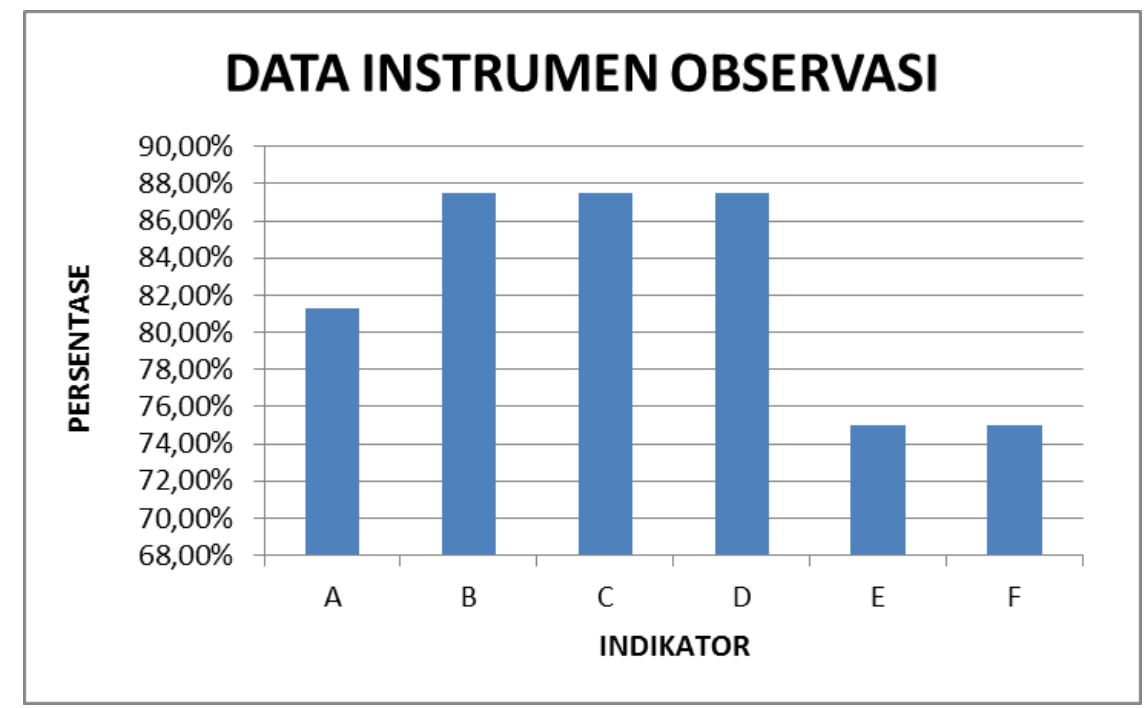

Gambar 2. Diagram profil kemandirian dalam menyelesaikan tugas dalam pembelajaran kewirausahaan kelas IV menggunakan instrumen observasi

Ket: $\boldsymbol{A}=$ Percaya Diri; $\boldsymbol{B}=$ Mampu Bekerja Sendiri; $\boldsymbol{C}=$ Menghargai Waktu; $\boldsymbol{D}=$ Bertanggungjawab; $\boldsymbol{E}=$ Hasrat Bersaing Untuk Maju; $\boldsymbol{F}=$ Mampu Mengambil Keputusan.

Pertama, indikator percaya diri yang terdiri aspek berani tampil di muka umum, percaya kepada kemampuan diri sendiri, berani bertanya saat menemui kesulitan, berani mengemukakan pendapat, berbicara lancar saat berada di hadapan orang banyak. Dari perhitungan data menggunakan angket menunjukkan persentase $83,33 \%$ dan $81,25 \%$ dari instrumen observasi. Dengan demikian tingkat kemandirian siswa pada indikator percaya diri berada pada kriteria baik. Setiap aspek sudah menunjukkan pada kategori baik.

Pada indikator mampu bekerja sendiri, dari aspek melakukan tugas tanpa 
diperintah orang lain dan menyelesaikan tugas tanpa bantuan orang lain. Dari perhitungan data menggunakan angket menunjukkan persentase $82,14 \%$ dan $87,50 \%$ dari instrumen observasi. Jadi, tingkat kemandirian siswa pada indikator mampu bekerja sendiri berada pada kriteria baik. Setiap aspek sudah menunjukkan pada kategori baik.

Kedua, indikator menghargai waktu yang terdiri aspek memanfaatkan waktu luang untuk kegiatan yang bermanfaat dan tidak menunda tugas. Dari perhitungan data menggunakan angket menunjukkan persentase $84,22 \%$ dan $87,50 \%$ dari instrumen observasi. Jadi, tingkat kemandirian siswa pada indikator menghargai waktu berada pada kriteria baik. Setiap aspek sudah menunjukkan pada kategori baik.

ketiga indikator bertanggung jawab yang terdiri aspek berani mengakui kesalahan dan berani menerima risiko atas perbuatan yang dilakukan. Dari perhitungan data menggunakan angket menunjukkan persentase $84,52 \%$ dan $87,50 \%$ dari instrumen observasi. Jadi, tingkat kemandirian siswa pada indikator bertanggung jawab berada pada kriteria baik.

Keempat, indikator memiliki hasrat bersaing untuk maju yang terdiri aspek rasa ingin tahu yang tinggi, dan mempunyai kreativitas yang tinggi. Dari perhitungan data menggunakan angket menunjukkan persentase $74,40 \%$ dan $75 \%$ dari instrumen observasi. Dengan demikian tingkat kemandirian siswa pada indikator memiliki hasrat bersaing untuk maju berada pada kriteria cukup baik.

Kelima, indikator mampu mengambil keputusan yang terdiri aspek hati-hati dalam mengambil keputusan, dan mampu menyelesaikan, masalah sendiri. Dari perhitungan data menggunakan angket menunjukkan persentase $75 \%$ dan $75 \%$ dari instrumen observasi. Jadi, tingkat kemandirian siswa pada indikator mampu mengambil keputusan berada pada kriteria cukup baik.

Berdasarkan data tersebut dapat dideskripsikan bahwa yang berada pada kategori baik adalah percaya diri, mampu bekerja sendiri, menghargai waktu, dan bertanggung jawab. Sedangkan pada kategori cukup baik adalah memiliki hasrat bersaing untuk maju dan mampu mengambil keputusan.

Kemandirian siswa kelas IV di SD Negeri 2 Waluyo sudah menunjukkan pada ranah baik. Siswa telah memiliki kemampuan percaya diri yang baik melalui kegiatan pembuatan produk, siswa mampu bertanya dan memberi tanggapan pada saat pembelajaran kewirausahaan. Siswa mampu bekerja sendiri ketika guru memberikan tugas individu membuat kerajinan dari manik-manik, dan sudah mampu menghargai waktu yaitu dengan disiplin dalam mengikuti pembelajaran kewirausahaan dan mengikuti jadwal waktu yang telah ditetapkan di sekolah. Sikap bertanggung jawab siswa berada pada kategori baik dimana pada aspek berani menerima risiko atas perbuatan yang dilakukan sudah dimunculkan dalam pembelajaran, yaitu ketika produk kerajinan manik-manik telah mencapai pada tahap penjualan dan produk tersebut tidak terjual, maka siswa pembuat produklah yang akan bertanggung jawab menjual hasil karyanya sendiri kepada orang lain hingga produknya terjual. Kemudian dalam pengambilan keputusan, siswa juga telah berada pada kategori baik. Dibuktikan dalam pembelajaran kewirausahaan dimana pada saat pembuatan produk, siswa sangat hatihati dalam pemilihan manik-manik yang akan digunakan untuk membuat gelang atau kalung. Hal ini sejalan dengan pendapat Hananta (2015:82) yang mengemukakan bahwa kemandirian muncul karena adanya ide dari diri sendiri dan kemampuan pengambilan keputusan yang serba hati-hati. Sedangkan pada kategori cukup baik adalah siswa memiliki hasrat bersaing untuk maju ditunjukkan dengan sikap tekun dan berfikir kreatif dalam pembuatan produk berupa gelang atau kalung yang terbuat dari manik-manik. Namun jiwa kreativitas siswa masih kurang karena dalam pembuatan produk, siswa diberi arahan untuk memilih membuat produk berupa kalung atau gelang. Hasil ini sejalan dengan penelitian Sumarti, et al., (2014), bahwa produk yang akan dibuat siswa sudah ditentukan oleh guru sehingga tingkat kekreativitasan siswa 
kurang. Diperkuat dengan gagasan pada penelitian Paristiowati, et al., (2015) yang menyatakan bahwa kreativitas siswa akan tampak ketika mereka diberi kebebasan untuk merancang suatu produk. Selanjutnya kemandirian pada aspek mengambil keputusan berada pada kategori cukup baik. Perlu di tingkatkan kemampuan siswa dalam mengambil keputusan agar siswa berani dan mampu menentukan keputusan yang tepat terhadap suatu masalah yang siswa hadapi.

\section{SIMPULAN}

Kemandirian siswa terdiri atas aspek percaya diri, mampu bekerja sendiri, menghargai waktu, bertanggung jawab, memiliki hasrat bersaing untuk maju, dan memiliki mampu mengambil keputusan. Kemandirian yang berada pada kategori baik adalah percaya diri, mampu bekerja sendiri, menghargai waktu, bertanggung jawab. Sedangkan pada kategori cukup baik adalah memiliki hasrat bersaing untuk maju, dan mengambil keputusan.

\section{DAFTAR PUSTAKA}

Ali, M. (2013). Prosedur dan Strategi Penelitian Pendidikan. Bandung: Angkasa.

Ali, M., dan Asrori, M. (2012). Psikologi Remaja: Perkembangan Peserta Didik. Jakarta: PT. Bumi Aksara.

Gea, Antonius Atosakhi, dkk. (2012). Character Building 1 Relasi dengan Diri Sendiri (edisi revisi). Jakarta: PT. Elex Media Komputindo.

Hananta, A. T. (2015). Studi Eksplorasi Pendidikan Kewirausahaan Di Sekolah Dasar Unggulan Aisiyah Bantul. Fakultas IImu Pendidikan. Universitas Negeri Yogyakarta.

Paristiowati, M.R., Slamet dan Sebastian, R., (2015), Chemo- entrepreneurship: learning approach for improving student's cooperation and communicatio, Procedia-Social and Behavioral Sciences, Vol 1, No 4, Hal. 1723-1730.

Riduwan. (2012). Belajar Mudah Penelitian Untuk Guru, Karyawan, Peneliti, Pemula. Bandung: Alfabeta

Sugiyono. (2013). Metode Penelitian Kuantitatif, Kualitatif, dan R\&D. Bandung: Alfabeta

Sumarti, S.S., Supartono dan Diniy H.H., (2014), Material Module Development of Colloid Orienting on Local-Advantage- Based Chemo-Entrepreneurship to Improve Student's Softskill, International Journal of Humanities and Management Sciences (IJHMS), Vol 2, No 1, Hal. 43-44.

Supartono. (2018). Analisis Hasil Belajar dan Minat Wirausaha Siswa Menggunakan Bahan Ajar Berorientasi Chemoentrepreneurship. Jurnal Inovasi Pendidikan, Vol 12, No. 1, 2018, halaman $2065-2074$.

Tursinawati. (2017). Analisis Kemandirian Siswa Dalam Proses Pembelajaran Di Kelas III SD Negeri 1 Banda Aceh. Jurnal Pesona Dasar Universitas Syiah Kuala Vol. 1 No.5, April 2017, hal. 70 -81 ISSN: 2337-9227. 